\title{
An Independent Effect of Osmolality on Urea Transport in Rat Terminal Inner Medullary Collecting Ducts
}

\author{
Jeff M. Sands and Dirk C. Schrader \\ Renal Division, Department of Medicine, Emory University School of Medicine, Atlanta, Georgia 30322
}

\begin{abstract}
We have shown that urea transport across the terminal inner medullary collecting duct (terminal IMCD) is mediated by a vasopressin-stimulated, facilitated diffusion process exhibiting properties consistent with a transporter. To investigate whether hypertonic $\mathrm{NaCl}$, as exists in vivo in the inner medulla, affects urea permeability, we studied isolated perfused rat terminal IMCD segments. Perfusate and bath osmolality were varied symmetrically by adding or removing $\mathrm{NaCl}$ or mannitol. Urea permeability rose progressively when osmolality was increased with $\mathrm{NaCl}$ or mannitol from 290 to $690 \mathrm{mOsm} / \mathrm{kg} \mathrm{H}_{2} \mathrm{O}$ in the absence of vasopressin; there was no further increase at $890 \mathrm{mOsm} / \mathrm{kg} \mathrm{H}_{2} \mathrm{O}$. In the presence of $10^{-8} \mathrm{M}$ arginine vasopressin, urea permeability increased when $\mathrm{NaCl}$ was added to raise osmolality from 290 to $490 \mathrm{mOsm} / \mathrm{kg} \mathrm{H}_{2} \mathrm{O}$ but there was no further increase at $690 \mathrm{mOsm} / \mathrm{kg} \mathrm{H}_{2} \mathrm{O}$. When $1 \mathrm{mM}$ 8bromo cyclic $\mathrm{AMP}$ was added to the bath, raising $\mathrm{NaCl}$ still increased urea permeability. These results suggest that urea transport across the rat terminal IMCD is regulated both by vasopressin and by osmolality at values present in the renal inner medulla. Osmolality seems to activate urea transport across the rat terminal IMCD by mechanisms distinct from those of vasopressin or cyclic AMP. (J. Clin. Invest. 1991. 88:137-142.) Key words: $\mathrm{NaCl} \bullet$ vasopressin • cyclic AMP • concentrating mechanism $\bullet$ hypertonicity
\end{abstract}

\section{Introduction}

Production of a concentrated urine requires that urea be delivered to the deepest portion of the renal inner medulla (1). This is possible because urea reabsorption is sharply limited until the terminal inner medullary collecting duct (terminal IMCD $^{1}$ ), located in the deepest two-thirds of the inner medulla $(2,3)$. We found that urea flux across the terminal IMCD involves a facilitated transport mechanism which is stimulated

Portions of this manuscript have been presented at the Annual Meeting of the Federation of American Societies for Experimental Biology, April 1991, Atlanta, GA, and have been published in abstract form (1991. FASEB (Fed. Am. Soc. Exp. Biol.) J. 5:A1110).

Address reprint requests to Dr. J. M. Sands, Emory University School of Medicine, Renal Division, 1364 Clifton Road NE, Atlanta, GA 30322.

Received for publication 16 November 1990 and in revised form 18 March 1991.

1. Abbreviation used in this paper: IMCD, inner medullary collecting duct.

J. Clin. Invest.

(c) The American Society for Clinical Investigation, Inc.

0021-9738/91/07/0137/06 \$2.00

Volume 88, July 1991, 137-142 by vasopressin but does not require energy (3). To date, no transport protein has been isolated. Evidence for a specific urea transporter in the terminal IMCD includes: (a) urea transport occurs too rapidly for simple paracellular transport or lipidphase diffusion (3), (b) urea transport is inhibited by phloretin and urea analogs (4), (c) solvent drag does not explain urea transport $(5,6)$, and $(d)$ there is saturation of thiourea transport (7).

During antidiuresis, the process of countercurrent multiplication generates steep axial gradients of $\mathrm{NaCl}$ and urea within the inner medulla. The physiology of concentrating the urine requires rapid transport of urea into the interstitium $(8,9)$. Vasopressin is important because it activates water reabsorption, thereby raising the concentration of urea in the tubule fluid reaching the terminal IMCD. If interstitial osmolality activated urea transport, it would augment urea delivery within the terminal two-thirds of the IMCD closest to the papillary tip. In the present studies, we explored the role of hypertonicity in regulating urea transport across the terminal IMCD to address three questions: ( $a$ ) does urea permeability increase in response to hypertonicity or to increasing $\mathrm{NaCl}$ alone; $(b)$ is vasopressin necessary for a change in urea permeability occurring with changes in osmolality; and (c) does a response to $\mathrm{NaCl}$ and vasopressin involve the same pathway?

\section{Methods}

\section{Experimental animals}

Pathogen-free male Sprague-Dawley rats weighing 75-120 g (Harlan Sprague Dawley Inc., Indianapolis, IN) were kept in filter-top cages with autoclaved bedding and fed autoclaved rat chow. The animals were maintained on a rat chow (NIH-31M; Ziegler Brothers Inc., Gardner, PA) which contained $56 \mathrm{mEq} / \mathrm{kg} \mathrm{Na}^{+}$and $259 \mathrm{mEq} / \mathrm{kg} \mathrm{K}{ }^{+}$ and were given food and water ad libitum. $20 \mathrm{~min}$ before the experiment, the animals were injected with furosemide ( $1 \mathrm{mg} / 100 \mathrm{~g} \mathrm{BW}$ IP) and terminal IMCD segments were dissected using methods described previously $(2,3)$.

Coronal slices of kidneys were transferred to a dissection dish containing chilled dissection solution $\left(17^{\circ} \mathrm{C}\right)$ which contained (in millimolar): $\mathrm{NaCl}, 118 ; \mathrm{NaHCO}_{3}, 25 ; \mathrm{CaCl}_{2}, 2 ; \mathrm{K}_{2} \mathrm{HPO}_{4}, 2.5 ; \mathrm{MgSO}_{4}, 1.2$; glucose, 5.5; and creatinine, 4 . Terminal IMCDs were dissected from a region $40-70 \%$ of the distance between the inner-outer medullary junction and the papillary tip and were perfused as described previously (10). After the tubule had been mounted on the pipettes, it was warmed to $37^{\circ} \mathrm{C}$ and allowed to equilibrate for $40 \mathrm{~min}$ before starting any collections (3). The same solution was used in the perfusate and bath except that $5 \mathrm{mM}$ urea was added to the bath solution and $5 \mathrm{mM}$ raffinose to the perfusion solution. This creates a $5 \mathrm{mM}$ bath-to-lumen urea gradient without an osmotic gradient (2). To avoid dissipation of the transepithelial urea gradient, perfusion rate was varied to maintain the collected urea concentration under $2.5 \mathrm{mM}$. Urea permeability did not vary with perfusion rate (Figs. 1 and 2) and was stable for up to $1 \mathrm{~h}$ at each osmolality (Fig. 2). The solution was gassed continuously with $95 \% \mathrm{O}_{2}$ and $5 \% \mathrm{CO}_{2}$ before and during the dissection $(2,3)$. Osmolality 


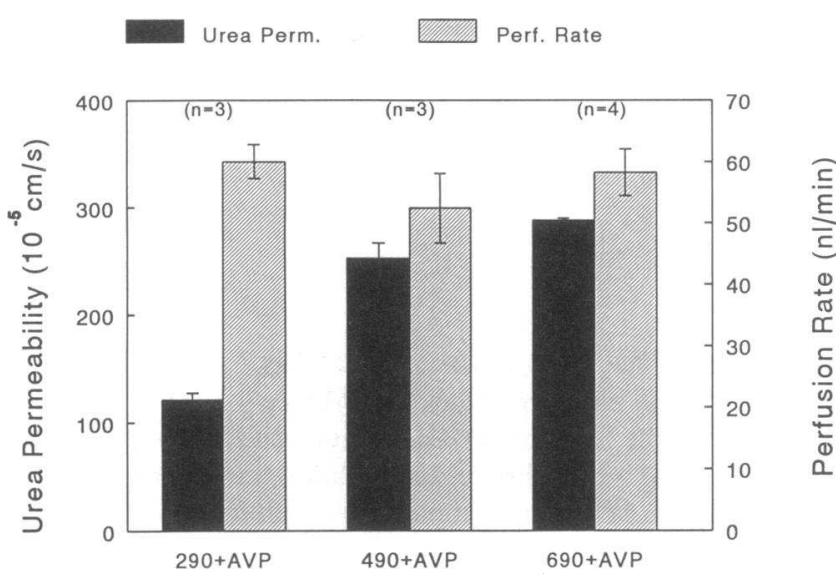

Figure 1. The perfusion rate does not change urea permeability. Shown are data from individual collections from a single tubule. Perfusion rate (hatched bars) was similar at each osmolality while urea permeability (solid bars) increased with increasing osmolality.

was measured by freezing point depression (Micro Osmette model 5004; Precision Systems, Inc., Natick, MA).

\section{Experimental protocols}

Effect of varying osmolality in the absence of vasopressin. After the 40-min equilibration period, three to four collections ( $\sim 50 \mathrm{nl}$ each) were obtained while perfusate and bath osmolality was $290 \mathrm{mOsm} / \mathrm{kg}$ $\mathrm{H}_{2} \mathrm{O}$. Next, both perfusate and bath osmolality were increased to 490 $\mathrm{mOsm} / \mathrm{kg} \mathrm{H}_{2} \mathrm{O}, 690 \mathrm{mOsm} / \mathrm{kg} \mathrm{H}_{2} \mathrm{O}$, and $890 \mathrm{mOsm} / \mathrm{kg} \mathrm{H}_{2} \mathrm{O}$ by adding either $\mathrm{NaCl}$ or mannitol; three to four additional collections were made at each osmolality. As a control for the effects of time and increasing osmolality, half of the tubules were studied at $890 \mathrm{mOsm} / \mathrm{kg}$ $\mathrm{H}_{2} \mathrm{O}$ in the first period, followed by reducing the osmolality progressively to $690 \mathrm{mOsm} / \mathrm{kg} \mathrm{H}_{2} \mathrm{O}, 490 \mathrm{mOsm} / \mathrm{kg} \mathrm{H}_{2} \mathrm{O}$, and $290 \mathrm{mOsm} / \mathrm{kg}$ $\mathrm{H}_{2} \mathrm{O}$ in subsequent periods. These tubules were dissected in isotonic medium and perfused with isotonic perfusate and bath for $15 \mathrm{~min}$. Perfusate and bath osmolalities were then increased to $890 \mathrm{mOsm} / \mathrm{kg}$ $\mathrm{H}_{2} \mathrm{O}$ for the remainder of the 40-min equilibration period.

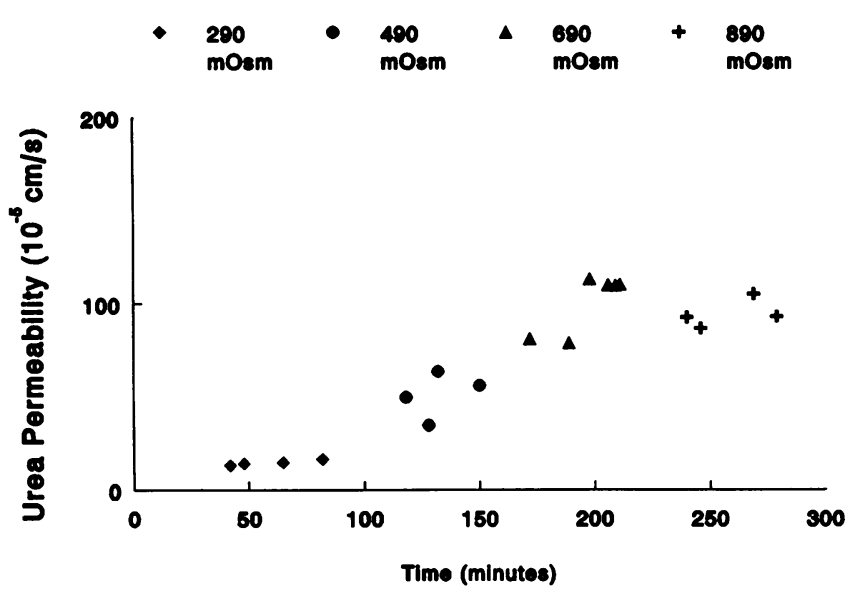

Figure 2. Temporal stability of urea permeability at each osmolality. Each point represents urea permeability measured during a single collection. Time 0 was when the tubule was warmed to $37^{\circ} \mathrm{C}$. At each osmolality, urea permeability was stable over $1 \mathrm{~h}$. The perfusion rate (nanoliters per minute) of the individual collections (from left to right) were: at $290 \mathrm{mOsm}, 31,34,9,20$; at $490 \mathrm{mOsm}, 13,51,18$, 41; at 690 mOsm, 22, 41, 38, 40, 43, 42; at 890 mOsm, 38, 34, 42, 35 .
Effect of varying osmolality with vasopressin. After the equilibration period and baseline collections when perfusate and bath osmolalities were $290 \mathrm{mOsm} / \mathrm{kg} \mathrm{H}_{2} \mathrm{O}$, vasopressin ( $10 \mathrm{nM}$ ) or 8-bromo cyclic AMP ( $1 \mathrm{mM})$ was added to the bath and three to four additional collections were obtained. Subsequently, both perfusate and bath osmolality were increased to $490 \mathrm{mOsm} / \mathrm{kg} \mathrm{H}_{2} \mathrm{O}$ and $690 \mathrm{mOsm} / \mathrm{kg} \mathrm{H}_{2} \mathrm{O}$ by adding $\mathrm{NaCl}$. There were three to four additional collections at each osmolality in the presence of vasopressin or 8-bromo cyclic AMP. Previously we found that the water flux $\left(J_{\mathrm{v}}\right)$ is 0 under these conditions (reference 5 and unpublished data of Sands, J. M., H. Nonoguchi, and M. A. Knepper). ${ }^{2}$ As before, perfusate and bath osmolalities were increased to $690 \mathrm{mOsm} / \mathrm{kg} \mathrm{H}_{2} \mathrm{O}$ at the same time that vasopressin or 8-bromo cyclic AMP was added to the bath and osmolalities were decreased to 490 $\mathrm{mOsm} / \mathrm{kg} \mathrm{H}_{2} \mathrm{O}$ and $290 \mathrm{mOsm} / \mathrm{kg} \mathrm{H}_{2} \mathrm{O}$ and collections made in the presence of vasopressin or 8-bromo cyclic AMP in half of the tubules.

Urea measurement. The urea concentration in perfusate, bath, and collected fluid was measured using a continuous-flow ultramicro-fluorometric measurement (2). The method uses two enzymatic reactions: $(a)$ conversion of urea to ammonia catalyzed by urease, and $(b)$ reaction of the ammonia with alpha-ketoglutarate and NADH to form $\mathrm{NAD}^{+}$, catalyzed by glutamate dehydrogenase (Kit \#65-A; Sigma Chemical Co., St. Louis, MO). The disappearance of NADH is proportional to the urea present in the injected sample. The method is linear from 0-60 pmol urea and is capable of resolving differences of $4 \%$ or greater in urea concentration (2).

The urea transport rate is calculated as: $J_{\mathrm{u}}=C_{\mathrm{o}} V_{\mathrm{o}}-C_{\mathrm{L}} V_{\mathrm{L}}$, where $C_{\mathrm{o}}$ is the urea concentration in the perfusate, $C_{\mathrm{L}}$ is the urea concentration in the collected fluid, $V_{0}$ is the perfusion rate per unit tubule length, and $V_{\mathrm{L}}$ is the collection rate per unit tubule length. As $C_{\mathrm{o}}=0$ in these experiments, this equation simplifies to: $J_{\mathrm{u}}=-C_{\mathrm{L}} V_{\mathrm{L}}$. The urea permeability is calculated from the urea transport rate $\left(J_{u}\right)$ as:

$P_{\mathrm{u}}=J_{\mathrm{u}} /\left(\pi \mathrm{ID}{ }^{*} C_{\mathrm{lm}}\right)$, where $C_{\mathrm{lm}}$ is the log-mean urea concentration difference along the tubule and ID is the tubule inner diameter.

Statistics. Data from three to four collections were averaged to obtain a single value for each experimental period in each tubule. Data are presented as mean $\pm \mathrm{SE}$. Testing of statistical significance employed one-way analysis of variance, with a multiple-comparisons, protected $t$ test to determine which groups were significantly different. The criterion for statistical significance was $P<0.05$.

\section{Results}

Effect of changing osmolality with $\mathrm{NaCl}$. Urea permeability increased as osmolality was raised from $290 \mathrm{mOsm} / \mathrm{kg} \mathrm{H}_{2} \mathrm{O}$ to $690 \mathrm{mOsm} / \mathrm{kg} \mathrm{H}_{2} \mathrm{O}$ by the addition of $\mathrm{NaCl}$ in the absence of vasopressin (Table I). There was no further increase in urea permeability at $890 \mathrm{mOsm} / \mathrm{kg} \mathrm{H}_{2} \mathrm{O}$ and there was no difference in the response of tubules in which osmolality was progressively increased from $290 \mathrm{mOsm} / \mathrm{kg} \mathrm{H}_{2} \mathrm{O}$ to $890 \mathrm{mOsm} / \mathrm{kg}$ $\mathrm{H}_{2} \mathrm{O}$ (Fig. 3, solid lines) or decreased from $890 \mathrm{mOsm} / \mathrm{kg} \mathrm{H}_{2} \mathrm{O}$ to $290 \mathrm{mOsm} / \mathrm{kg} \mathrm{H}_{2} \mathrm{O}$ (Fig. 3, dashed lines).

Effect of changing osmolality with mannitol. Urea permeability (in the absence of vasopressin) also increased when mannitol was used to raise osmolality from $290 \mathrm{mOsm} / \mathrm{kg} \mathrm{H}_{2} \mathrm{O}$ to $490 \mathrm{mOsm} / \mathrm{kg} \mathrm{H}_{2} \mathrm{O}$; at $490 \mathrm{mOsm} / \mathrm{kg} \mathrm{H}_{2} \mathrm{O}$ a plateau value was reached (Table II). There was no difference in the response of tubules in which osmolality was progressively increased

2. Although not published in reference 7 , we measured water flux $\left(J_{\mathrm{v}}\right)$ in the six tubules presented in Fig. 1 of that paper, using methods described in reference 5 . In the presence of vasopressin, $J_{\mathrm{v}}$ was $-0.45 \pm 0.70$, not significantly different from 0 when perfusate and bath osmolalities were $680 \mathrm{mOsm} / \mathrm{kg} \mathrm{H}_{2} \mathrm{O}$. These results are consistent with the absence of a transepithelial osmotic gradient (unpublished data of Sands, J. M., H. Nonoguchi, and M. A. Knepper). 
Table I. Effect of Changing Osmolality with $\mathrm{NaCl}$

\begin{tabular}{|c|c|c|c|c|c|c|c|}
\hline \multirow[b]{2}{*}{ Osmolality } & \multirow{2}{*}{$\begin{array}{l}\text { Perfusion } \\
\text { rate }\end{array}$} & \multicolumn{3}{|c|}{ Urea concentration } & \multirow{2}{*}{$\begin{array}{c}\text { Urea } \\
\text { grad }_{\text {lm }}\end{array}$} & \multirow[b]{2}{*}{$J_{\text {urre }}$} & \multirow[b]{2}{*}{$P_{\text {urea }}$} \\
\hline & & Perfusion & Bath & Collection & & & \\
\hline mOsm & $n l / m$ & $m M$ & $m M$ & $m M$ & $m M$ & $\mathrm{pmol} / \mathrm{mm} / \mathrm{m}$ & $\times 10^{-5} \mathrm{~cm} / \mathrm{s}$ \\
\hline \multirow[t]{2}{*}{290} & 32.30 & 0.00 & 4.90 & 0.88 & 4.43 & 70.6 & $34.9^{*}$ \\
\hline & \pm 5.34 & \pm 0.00 & \pm 0.08 & \pm 0.07 & \pm 0.10 & \pm 14.1 & \pm 6.6 \\
\hline \multirow[t]{2}{*}{490} & 42.73 & 0.00 & 4.96 & 1.71 & 3.96 & 161.2 & $90.9^{*}$ \\
\hline & \pm 7.07 & \pm 0.00 & \pm 0.09 & \pm 0.26 & \pm 0.23 & \pm 20.7 & \pm 10.6 \\
\hline \multirow[t]{2}{*}{690} & 55.79 & 0.00 & 5.00 & 1.98 & 3.83 & 246.6 & $142.7^{*}$ \\
\hline & \pm 8.75 & \pm 0.00 & \pm 0.10 & \pm 0.34 & \pm 0.27 & \pm 48.6 & \pm 28.0 \\
\hline \multirow[t]{2}{*}{890} & 55.50 & 0.00 & 4.98 & 1.70 & 4.01 & 215.2 & $118.9^{\ddagger}$ \\
\hline & \pm 8.64 & \pm 0.00 & \pm 0.12 & \pm 0.30 & \pm 0.22 & \pm 15.9 & \pm 8.7 \\
\hline
\end{tabular}

Data are presented as mean $\pm \mathrm{SE}(n=6)$. Tubule length, $0.37 \pm 0.02$. Tubule inner diameter, $24.7 \pm 1.8 .{ }^{*}$ These values are significantly different from one another by ANOVA $(P<0.05) .{ }^{\ddagger}$ This value is significantly different from $290 \mathrm{mOsm} / \mathrm{kg} \mathrm{H} \mathrm{H}_{2} \mathrm{O}$, but not from $490 \mathrm{mOsm} / \mathrm{kg} \mathrm{H} \mathrm{H}_{2} \mathrm{O}$ or $690 \mathrm{mOsm} / \mathrm{kg} \mathrm{H}_{2} \mathrm{O}$ by ANOVA. Grad ${ }_{l \mathrm{~m}}$, log-mean urea gradient; $J_{\text {urea }}$, urea flux; $P_{\text {urea }}$, urea permeability.

from $290 \mathrm{mOsm} / \mathrm{kg} \mathrm{H}_{2} \mathrm{O}$ to $890 \mathrm{mOsm} / \mathrm{kg} \mathrm{H}_{2} \mathrm{O}$ (Fig. 4, solid lines) or progressively decreased from $890 \mathrm{mOsm} / \mathrm{kg} \mathrm{H} \mathrm{H}_{2} \mathrm{O}$ to $290 \mathrm{mOsm} / \mathrm{kg} \mathrm{H}_{2} \mathrm{O}$ (Fig. 4, dashed lines). When the effects of mannitol and $\mathrm{NaCl}$ were compared, urea permeability was significantly lower (by ANOVA) at $690 \mathrm{mOsm} / \mathrm{kg} \mathrm{H}_{2} \mathrm{O}$ with mannitol but not at other osmolalities tested (Tables I and II).

Effect of changing osmolality in the presence of vasopressin. Urea permeability also increased when $\mathrm{NaCl}$ was added $(290$ $\mathrm{mOsm} / \mathrm{kg} \mathrm{H}_{2} \mathrm{O}$ ) in the presence of $10 \mathrm{nM}$ vasopressin at 290 $\mathrm{mOsm} / \mathrm{kg} \mathrm{H}_{2} \mathrm{O}$ (Table III). Permeability increased further as osmolality was increased from $290 \mathrm{mOsm} / \mathrm{kg} \mathrm{H}_{2} \mathrm{O}$ to 490 $\mathrm{mOsm} / \mathrm{kg} \mathrm{H} \mathrm{H}_{2} \mathrm{O}$ but not at $690 \mathrm{mOsm} / \mathrm{kg} \mathrm{H}_{2} \mathrm{O}$ (Table III). Again, there was no difference in the response of tubules when the osmolality was progressively increased from $290 \mathrm{mOsm} / \mathrm{kg}$ $\mathrm{H}_{2} \mathrm{O}$ to $690 \mathrm{mOsm} / \mathrm{kg} \mathrm{H}_{2} \mathrm{O}$ (Fig. 5, solid lines) or decreased from $690 \mathrm{mOsm} / \mathrm{kg} \mathrm{H} \mathrm{H}_{2} \mathrm{O}$ to $290 \mathrm{mOsm} / \mathrm{kg} \mathrm{H}_{2} \mathrm{O}$ (Fig. 5, dashed lines). The increase in permeability from $290 \mathrm{mOsm} / \mathrm{kg} \mathrm{H}_{2} \mathrm{O}$ to $490 \mathrm{mOsm} / \mathrm{kg} \mathrm{H}_{2} \mathrm{O}$ in the presence of a supraphysiologic con-

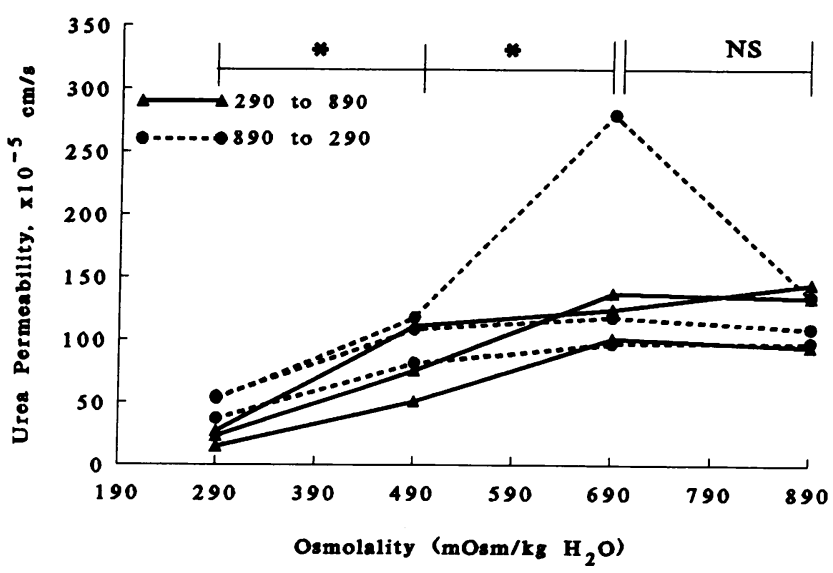

Figure 3. Effect of changing osmolality by adding or removing $\mathrm{NaCl}$ in the absence of vasopressin on passive urea permeability in rat terminal IMCDs. Each line connects data from an individual tubule. Solid lines represent tubules in which osmolality was increased. Dotted lines represent tubules in which osmolality was decreased. ${ }^{*} P$ $<0.05$ by ANOVA. centration of vasopressin was not different statistically (by $t$ test) from the change induced by osmolality alone.

Effect of changing osmolality in the presence of 8-bromo cyclic AMP. At $290 \mathrm{mOsm} / \mathrm{kg} \mathrm{H}_{2} \mathrm{O}$, addition of $1 \mathrm{mM} 8$-bromo cyclic AMP increased urea permeability and there was a further increase when osmolality was increased to $490 \mathrm{mOsm} / \mathrm{kg} \mathrm{H}_{2} \mathrm{O}$ by adding $\mathrm{NaCl}$ (Table IV). As with vasopressin, there was no further increase in urea permeability at $690 \mathrm{mOsm} / \mathrm{kg} \mathrm{H} \mathrm{H}_{2} \mathrm{O}$ (Table IV). 8-Bromo cyclic AMP (1 mM) and vasopressin (10 nM) stimulated urea permeability similarly at all osmolalities tested. There was no difference in the response of tubules in which osmolality was progressively increased from $290 \mathrm{mOsm} /$ $\mathrm{kg} \mathrm{H}_{2} \mathrm{O}$ to $690 \mathrm{mOsm} / \mathrm{kg} \mathrm{H}_{2} \mathrm{O}$ (Fig. 6, solid lines) or decreased from $690 \mathrm{mOsm} / \mathrm{kg} \mathrm{H}_{2} \mathrm{O}$ to $290 \mathrm{mOsm} / \mathrm{kg} \mathrm{H}_{2} \mathrm{O}$ (Fig. 6, dashed lines). As with results in the presence of vasopressin, osmolality alone stimulated urea permeability as much as a high concentration of 8-bromo cyclic AMP.

\section{Discussion}

Our previous work established that urea is transported by a facilitated diffusion pathway in isolated perfused rat terminal IMCDs $(2,3)$. The present results extend information on this pathway by demonstrating that hypertonic $\mathrm{NaCl}$ or mannitol increases urea permeability in the absence of vasopressin and that hypertonic $\mathrm{NaCl}$ and vasopressin have additive effects on urea permeability. Osmolality exerts its effect on urea permeability independent of cyclic AMP and appears to act by a mechanism different from that of vasopressin and cyclic AMP. Thus, urea transport in the rat terminal IMCD is regulated by two separate stimuli: vasopressin and inner medullary osmolality and hence, $\mathrm{NaCl}$ concentration.

Our previous studies have shown that the urea transporter can function either to reabsorb or secrete urea, depending upon the direction of the imposed urea gradient $(2,7)$. In the present study, we chose to measure urea transport only in the secretory direction, obviating the need to measure water flux simultaneously (3). We varied perfusate and bath osmolality symmetrically to eliminate transepithelial gradients for water or $\mathrm{NaCl}$ movement and hence, the possibility that solvent drag would influence the results. To ensure that the increase in urea perme- 
Table II. Effect of Changing Osmolality with Mannitol

\begin{tabular}{|c|c|c|c|c|c|c|c|}
\hline \multirow[b]{2}{*}{ Osmolality } & \multirow{2}{*}{$\begin{array}{l}\text { Perfusion } \\
\text { rate }\end{array}$} & \multicolumn{3}{|c|}{ Urea concentration } & \multirow{2}{*}{$\underset{\text { grad }_{l m}}{\text { Urea }}$} & \multirow[b]{2}{*}{$J_{\text {wrea }}$} & \multirow[b]{2}{*}{$P_{\text {uree }}$} \\
\hline & & Perfusion & Bath & Collection & & & \\
\hline mOsm & $n l / m$ & $m M$ & $m M$ & $m M$ & $m M$ & $\mathrm{pmol} / \mathrm{mm} / \mathrm{m}$ & $\times 10^{-5} \mathrm{~cm} / \mathrm{s}$ \\
\hline \multirow[t]{2}{*}{290} & 28.76 & 0.00 & 4.91 & 0.73 & 4.53 & 58.7 & 28.0 \\
\hline & \pm 1.68 & \pm 0.00 & \pm 0.06 & \pm 0.09 & \pm 0.07 & \pm 11.1 & \pm 5.1 \\
\hline \multirow[t]{2}{*}{490} & 44.04 & 0.00 & 4.90 & 1.17 & 4.26 & 143.2 & $74.9^{*}$ \\
\hline & \pm 3.55 & \pm 0.00 & \pm 0.09 & \pm 0.22 & \pm 0.20 & \pm 17.9 & \pm 12.9 \\
\hline \multirow[t]{2}{*}{690} & 42.03 & 0.00 & 4.81 & 1.39 & 4.05 & 166.9 & $92.0^{* *}$ \\
\hline & \pm 2.87 & \pm 0.00 & \pm 0.13 & \pm 0.15 & \pm 0.18 & \pm 18.9 & \pm 14.9 \\
\hline \multirow[t]{2}{*}{890} & 43.73 & 0.00 & 4.75 & 1.21 & 4.09 & 143.8 & $79.5^{*}$ \\
\hline & \pm 2.72 & \pm 0.00 & \pm 0.12 & \pm 0.19 & \pm 0.21 & \pm 22.9 & \pm 17.6 \\
\hline
\end{tabular}

Data are presented as mean $\pm \operatorname{SE}(n=6)$. Tubule length, $0.35 \pm 0.03$. Tubule inner diameter, $24.7 \pm 0.3{ }^{*}$ These values are significantly different from $290 \mathrm{mOsm} / \mathrm{kg} \mathrm{H}_{2} \mathrm{O}$, but not from each other by ANOVA. ${ }^{\ddagger}$ This value is significantly different from the urea permeability at 690 $\mathrm{mOsm} / \mathrm{kg} \mathrm{H}_{2} \mathrm{O}$ with added $\mathrm{NaCl}$. Grad $\mathrm{Im}_{\mathrm{m}}$, log-mean urea gradient; $J_{\text {urea }}$, urea flux; $\boldsymbol{P}_{\text {urea }}$, urea permeability.

ability with changes in osmolality was not due to nonspecific effects or osmotic damage to the tubule, osmolality was increased in half of the tubules and decreased in the other half in each experimental protocol. The results were similar regardless of whether osmolality was raised or lowered (Figs. 3-6), indicating that the changes in urea permeability resulted from changes in osmolality. Urea permeability was stable at each osmolality for up to $1 \mathrm{~h}$ (Fig. 2) and was independent of perfusion rate (Figs. 1 and 2).

Previously, we reported that adding $\mathrm{NaCl}$ to increase osmolality from $290 \mathrm{mOsm} / \mathrm{kg} \mathrm{H} \mathrm{H}_{2} \mathrm{O}$ to $690 \mathrm{mOsm} / \mathrm{kg} \mathrm{H} \mathrm{H}_{2} \mathrm{O}$ by adding $\mathrm{NaCl}$ resulted in a doubling of urea permeability in the presence of a physiologic concentration of vasopressin $\left(10^{-11}\right.$ M) (7). The present study extends this result by showing that the stimulus is osmolality rather than $\mathrm{NaCl}$ alone. Moreover, the stimulation occurs in the absence of vasopressin and is additive to supraphysiologic concentrations of vasopressin

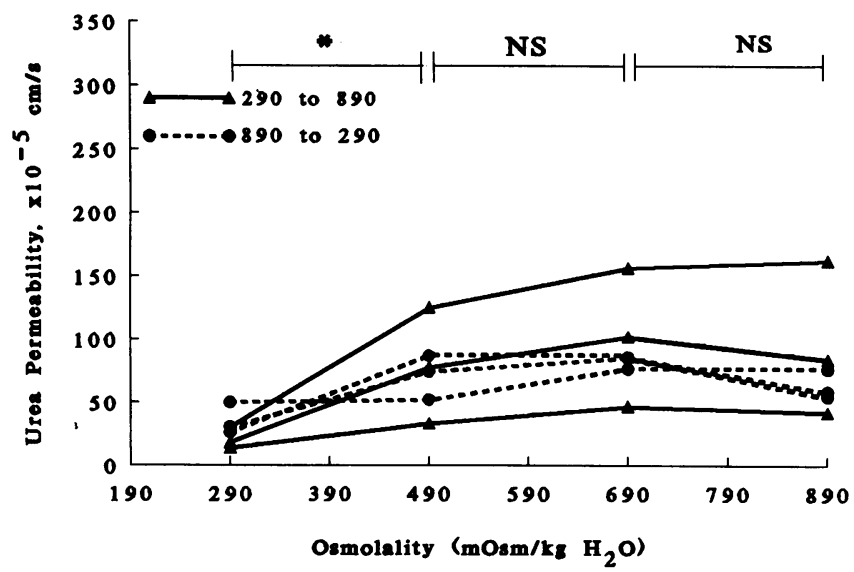

Figure 4. Effect of changing osmolality by adding or removing mannitol in the absence of vasopressin on passive urea permeability in rat terminal IMCDs. Each line connects data from an individual tubule. Solid lines represent tubules in which osmolality was increased. Dotted lines represent tubules in which osmolality was decreased. ${ }^{*} P$ $<0.05$ by ANOVA. $\left(10^{-8} \mathrm{M}\right)$. Finally, the effect of osmolality is additive to cyclic AMP.

Cyclic AMP is the second messenger which mediates the effect of vasopressin on urea permeability (11) and osmotic water permeability (12) in rat terminal IMCDs. Hypertonic $\mathrm{NaCl}$ and vasopressin have additive effects on adenylyl cyclase activity and cyclic AMP production in the inner medulla (1316). To test whether hypertonic $\mathrm{NaCl}$ was increasing urea permeability by increasing cyclic AMP production, we pretreated tubules with $1 \mathrm{mM} 8$-bromo cyclic AMP. The effect of hypertonic $\mathrm{NaCl}$ was additive to that of 8-bromo cyclic AMP on urea permeability, suggesting that the effect of hypertonic $\mathrm{NaCl}$ was independent of cyclic AMP. Whether hypertonic $\mathrm{NaCl}$ also has a cyclic AMP-dependent effect cannot be determined from the present study.

Studies by Chou et al. (7) have shown that hypertonic urea, added to perfusate and bath, decreases urea permeability in the

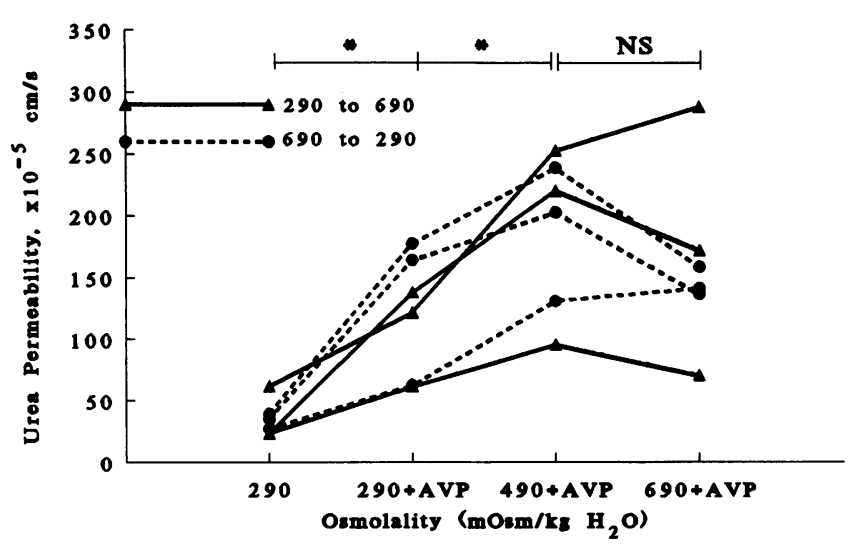

Figure 5. Effect of changing osmolality by adding or removing $\mathrm{NaCl}$ in the presence of $10 \mathrm{nM}$ vasopressin on passive urea permeability in rat terminal IMCDs. Each line connects data from an individual tubule. (Solid lines) Tubules in which osmolality was increased. (Dotted lines) Tubules in which osmolality was decreased. ${ }^{*} P<0.05$ by ANOVA. 
Table III. Effect of Changing Osmolality with $\mathrm{NaCl}$ and $10 \mathrm{nM}$ Vasopressin

\begin{tabular}{|c|c|c|c|c|c|c|c|c|}
\hline \multirow[b]{2}{*}{ Osmolality } & \multirow[b]{2}{*}{ AVP } & \multirow{2}{*}{$\begin{array}{l}\text { Perfusion } \\
\text { rate }\end{array}$} & \multicolumn{3}{|c|}{ Urea concentration } & \multirow{2}{*}{$\begin{array}{c}\text { Urea } \\
\text { grad }_{\text {im }}\end{array}$} & \multirow[b]{2}{*}{$J_{\text {wres }}$} & \multirow[b]{2}{*}{$P_{\text {uree }}$} \\
\hline & & & Perfusion & Bath & Collection & & & \\
\hline mOsm & $n M$ & $n l / m$ & $m M$ & $m M$ & $m M$ & $m M$ & $\mathrm{pmol} / \mathrm{mm} / \mathrm{m}$ & $\times 10^{-5} \mathrm{~cm} / \mathrm{s}$ \\
\hline \multirow[t]{2}{*}{290} & 0 & 35.50 & 0.00 & 4.84 & 0.61 & 4.52 & 73.7 & $34.8^{*}$ \\
\hline & & \pm 3.80 & \pm 0.00 & \pm 0.11 & \pm 0.07 & \pm 0.13 & \pm 7.8 & \pm 6.0 \\
\hline \multirow[t]{2}{*}{290} & 10 & 60.03 & 0.00 & 4.84 & 1.14 & 4.23 & 240.4 & $120.9^{*}$ \\
\hline & & \pm 7.72 & \pm 0.00 & \pm 0.11 & \pm 0.16 & \pm 0.15 & \pm 38.2 & \pm 20.3 \\
\hline \multirow[t]{2}{*}{490} & 10 & 61.07 & 0.00 & 4.92 & 1.61 & 4.03 & 359.1 & $190.4^{*}$ \\
\hline & & \pm 5.99 & \pm 0.00 & \pm 0.14 & \pm 0.19 & \pm 0.23 & \pm 37.7 & \pm 25.6 \\
\hline \multirow[t]{2}{*}{690} & 10 & 58.22 & 0.00 & 4.96 & 1.45 & 4.16 & 306.7 & $161.2^{\ddagger}$ \\
\hline & & \pm 6.00 & \pm 0.00 & \pm 0.15 & \pm 0.17 & \pm 0.25 & \pm 31.0 & \pm 29.2 \\
\hline
\end{tabular}

Data are presented as mean $\pm \mathrm{SE}(n=6)$. Tubule length, $0.27 \pm 0.04$. Tubule inner diameter, $26.3 \pm 2.0{ }^{*}$ These values are significantly different from one another by ANOVA $(P<0.05)$. ${ }^{\ddagger}$ This value is significantly different from $290 \mathrm{mOsm} / \mathrm{kg} \mathrm{H}_{2} \mathrm{O}$ without AVP, but not from 290 $\mathrm{mOsm} / \mathrm{kg} \mathrm{H}_{2} \mathrm{O}$ or $490 \mathrm{mOsm} / \mathrm{kg} \mathrm{H}_{2} \mathrm{O}$ with AVP by ANOVA. $\mathrm{Grad}_{\mathrm{lm}}$, log-mean urea gradient; $J_{\text {urea }}$, urea flux; $P_{\text {urea }}$, urea permeability.

presence of $10^{-10} \mathrm{M}$ vasopressin. Thus, effective osmoles $(\mathrm{NaCl}$, mannitol) stimulate urea permeability, whereas ineffective osmoles (urea) inhibit urea permeability. Nadler has reported that hyperosmolality increases vasopressin-stimulated osmotic water permeability in rat terminal IMCDs (17). Because atrial natriuretic factor (12) inhibits vasopressin-stimulated osmotic water permeability but has no effect on urea permeability, the results suggest that osmotic water permeability and urea permeability can be regulated independently. The mechanism for differential regulation is not currently known.

The mechanism by which hypertonicity increases urea permeability cannot be determined from these experiments. It cannot be explained by a reduction in cell volume allowing urea to traverse the cell more rapidly, because the apical membrane is rate limiting for transepithelial urea transport (18). A second explanation is that hypertonicity induces a physical change in the conformation of the urea transporter. While stimulation of urea transport by both hypertonic $\mathrm{NaCl}$ and mannitol would be consistent with this hypothesis, inhibition of urea transport by hypertonic urea (7) suggests that this explanation is not sufficient. A third mechanism could involve a hypertonicity-induced change in intracellular volume (17) or composition which either activates preexisting transporters or causes their insertion into the membrane. Fourthly, changes in osmolality could initiate synthesis of new transporters, but this seems unlikely given the short time interval $(15 \mathrm{~min})$ between changes in osmolality and urea permeability.

Implications for the concentrating mechanism. The production of a concentrated urine depends, in part, upon delivery of urea to the deep inner medulla $(1,8,9)$. While previous studies explain how urea reabsorption is delayed until the terminal $\operatorname{IMCD}(2,3)$, they do not provide a mechanism by which urea reabsorption increases within the deepest two-thirds of the inner medulla. Vasopressin-stimulated water reabsorption from the more proximal, urea-impermeable, collecting duct segments concentrates urea within the lumen of the IMCD and establishes a concentration gradient favoring urea reabsorption $(2,3)$. An increase in interstitial $\mathrm{NaCl}$ concentration, resulting from countercurrent multiplication, could be synergistic to vasopressin in progressively increasing urea permeability and

Table IV. Effect of Changing Osmolality with $\mathrm{NaCl}$ and $1 \mathrm{mM}$ 8-Bromo Cyclic AMP

\begin{tabular}{|c|c|c|c|c|c|c|c|c|}
\hline \multirow[b]{2}{*}{ Osmolality } & \multirow[b]{2}{*}{ cAMP } & \multirow{2}{*}{$\begin{array}{l}\text { Perfusion } \\
\text { rate }\end{array}$} & \multicolumn{3}{|c|}{ Urea concentration } & \multirow{2}{*}{$\underset{\text { Urad }_{l \mathbf{m}}}{\text { Urea }}$} & \multirow[b]{2}{*}{$J_{\text {uree }}$} & \multirow[b]{2}{*}{$P_{\text {uree }}$} \\
\hline & & & Perfusion & Bath & Collection & & & \\
\hline mOsm & $m M$ & $n l / m$ & $m M$ & $m M$ & $m M$ & $m M$ & $\mathrm{pmol} / \mathrm{mm} / \mathrm{m}$ & $\times 10^{-5} \mathrm{~cm} / \mathrm{s}$ \\
\hline \multirow[t]{2}{*}{290} & 0 & 30.69 & 0.00 & 5.02 & 0.79 & 4.60 & 72.0 & $33.9^{*}$ \\
\hline & & \pm 2.79 & \pm 0.00 & \pm 0.04 & \pm 0.08 & \pm 0.07 & \pm 7.0 & \pm 4.2 \\
\hline \multirow[t]{2}{*}{290} & 1 & 41.12 & 0.00 & 5.02 & 1.51 & 4.19 & 184.3 & $98,9^{*}$ \\
\hline & & \pm 2.48 & \pm 0.00 & \pm 0.04 & \pm 0.19 & \pm 0.12 & \pm 11.7 & \pm 6.9 \\
\hline \multirow[t]{2}{*}{490} & 1 & 53.05 & 0.00 & 5.00 & 1.76 & 3.99 & 276.1 & $155.0^{*}$ \\
\hline & & \pm 3.60 & \pm 0.00 & \pm 0.03 & \pm 0.21 & \pm 0.16 & \pm 28.1 & \pm 14.7 \\
\hline \multirow[t]{2}{*}{690} & 1 & 54.40 & 0.00 & 4.97 & 1.76 & 3.99 & 303.1 & $174.2^{\ddagger}$ \\
\hline & & \pm 4.64 & \pm 0.00 & \pm 0.04 & \pm 0.13 & \pm 0.12 & \pm 45.6 & \pm 30.9 \\
\hline
\end{tabular}

Data are presented as mean $\pm \operatorname{SE}(n=6)$. Tubule length, $0.33 \pm 0.02$. Tubule inner diameter, $24.7 \pm 2.7{ }^{*}$ These values are significantly different from one another by ANOVA $(P<0.05) .{ }^{\ddagger}$ This value is significantly different from $290 \mathrm{mOsm} / \mathrm{kg} \mathrm{H}_{2} \mathrm{O}$ without or with cAMP, but not from $490 \mathrm{mOsm} / \mathrm{kg} \mathrm{H}_{2} \mathrm{O}$ with cAMP by ANOVA. Grad ${ }_{1 \mathrm{~m}}$, log-mean urea gradient; $J_{\text {urea }}$, urea flux; $P_{\text {urea }}$, urea permeability. 


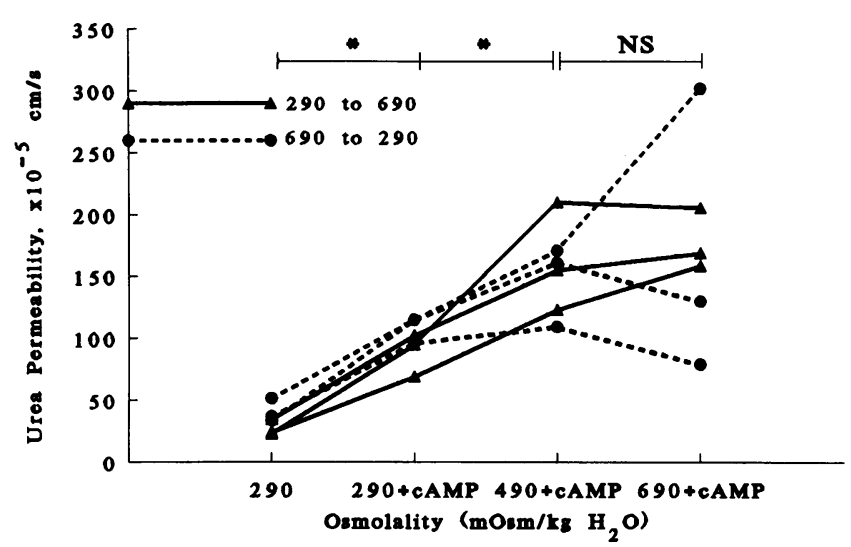

Figure 6. Effect of changing osmolality by adding or removing $\mathrm{NaCl}$ in the presence of $1 \mathrm{mM}$ 8-bromo cyclic AMP on passive urea permeability in rat terminal IMCDs. Each line connects data from an individual tubule. (Solid lines) Tubules in which osmolality was increased. (Dotted lines) Tubules in which osmolality was decreased. ${ }^{*} P<0.05$ by ANOVA.

stimulating urea reabsorption from the terminal IMCD. The increase in interstitial urea concentration would stimulate further $\mathrm{NaCl}$ reabsorption from the thin ascending limb, forming a positive-feedback loop for generating the hypertonic inner medulla necessary for antidiuresis. During diuresis, urea reabsorption would decrease because of a lower urea permeability resulting from lack of vasopressin, decreased interstitial $\mathrm{NaCl}$ concentration, and a decreased gradient favoring urea reabsorption resulting from lack of vasopressin-stimulated water reabsorption in the cortical collecting duct, outer medullary collecting duct, and initial IMCD.

\section{Acknowledgements}

The authors thank Drs. Juha P. Kokko, William E. Mitch, and Douglas C. Eaton for their critical reading of this manuscript.

This work was supported by National Institutes of Health grant R29-DK41707. J. M. Sands performed portions of this work during the tenure of an Established Investigatorship from the American Heart Association.

\section{References}

1. Berliner, R. W., N. G. Levinsky, D. G. Davidson, and M. Eden. 1958. Dilution and concentration of the urine and the action of antidiuretic hormone. Am. J. Med. 27:730-744.

2. Sands, J. M., and M. A. Knepper. 1987. Urea permeability of mammalian inner medullary collecting duct system and papillary surface epithelium. J. Clin. Invest. 79:138-147.

3. Sands, J. M., H. Nonoguchi, and M. A. Knepper. 1987. Vasopressin effects on urea and $\mathrm{H}_{2} \mathrm{O}$ transport in inner medullary collecting duct subsegments. Am. J. Physiol. 253:F823-F832.

4. Chou, C.-L., and M. A. Knepper. 1989. Inhibition of urea transport in inner medullary collecting duct by phloretin and urea analogues. Am. J. Physiol. 257:F359-F365.

5. Knepper, M. A., J. M. Sands, and C.-L. Chou. 1989. Independence of urea and water transport in rat inner medullary collecting duct. Am. J. Physiol. 256:F610-F621.

6. Chou, C.-L., J. M. Sands, H. Nonoguchi, and M. A. Knepper. 1990. Ureagradient associated fluid absorption with $\sigma_{\text {urea }}=1$ in rat terminal collecting duct. Am. J. Physiol. 258:F1173-F1180.

7. Chou, C.-L., J. M. Sands, H. Nonoguchi, and M. A. Knepper. 1990. Concentration dependence of urea and thiourea transport pathway in rat inner medullary collecting duct. Am. J. Physiol. 258:F486-F494.

8. Kokko, J. P., and F. C. Rector. 1972. Countercurrent multiplication system without active transport in inner medulla. Kidney Int. 2:214-223.

9. Stephenson, J. L. 1972. Concentration of urine in a central core model of the renal counterflow system. Kidney Int. 2:85-94.

10. Burg, M. B. 1972. Perfusion of isolated renal tubules. Yale J. Biol. Med. 45:321-326.

11. Star, R. A., H. Nonoguchi, R. Balaban, and M. A. Knepper. 1988. Calcium and cyclic adenosine monophosphate as second messengers for vasopressin in the rat inner medullary collecting duct. J. Clin. Invest. 81:1879-1888.

12. Nonoguchi, H., J. M. Sands, and M. A. Knepper. 1988. Atrial natriuretic factor inhibits vasopressin-stimulated osmotic water permeability in rat inner medullary collecting duct. J. Clin. Invest. 82:1383-1390.

13. Craven, P. A., R. Briggs, and F. R. DeRubertis. 1980. Calcium-dependent action of osmolality on adenosine $3^{\prime}, 5^{\prime}$-monophosphate accumulation in rat renal inner medulla. Evidence for a relationship to calcium-responsive arachidonate release and prostaglandin synthesis. J. Clin. Invest. 65:529-542.

14. Sato, M., and M. J. Dunn. 1986. Osmolality, vasopressin-stimulated cAMP, and $\mathrm{PGE}_{2}$ synthesis in rat collecting tubule cells. Am. J. Physiol. 250:F802-F810.

15. Edwards, R. M., B. A. Jackson, and T. P. Dousa. 1981. ADH-sensitive cAMP system in papillary collecting duct: effect of osmolality and $\mathrm{PGE}_{2} . \mathrm{Am}$. J. Physiol. 240:F311-F318.

16. Dousa, T. P. 1972. Effect of renal medullary solutes on vasopressin-sensitive adenyl cyclase. Am. J. Physiol. 222:657-662.

17. Nadler, S. P. 1990 . Effects of hypertonicity on ADH-stimulated water permeability in rat inner medullary collecting duct. Am. J. Physiol. 258:F266F272.

18. Star, R. A. 1990. Apical membrane limits urea permeation across the rat inner medullary collecting duct. J. Clin. Invest. 86:1172-1178. 